\title{
ANALISA PERAN KOMITE SEKOLAH DALAM PENINGKATAN MUTU PENDIDIKAN DI KECAMATAN BALIGE KABUPATEN TOBA SAMOSIR (Studi Komparatif SMA Negeri 1 Balige dan SMA Negeri 2 Balige)
}

\author{
Dearlina Sinaga \\ Program Studi Pendidikan Ekonomi Fakultas Keguruan Ilmu Pendidikan, Universitas HKBP Nommensen-Medan \\ E-mail: dr.dearlina @gmail.com
}

\begin{abstract}
ABSTRAK. Penelitian ini bertujuan untuk mengetahui perbedaan pelaksanaan peran komite sekolah di SMA Negeri 2 Balige dengan peran komite sekolah di SMA Negeri 1 Balige, dan apakah perbedaan peran tersebut memberi kontribusi terhadap peningkatan mutu pendidikan di kedua sekolah tersebut. Pendekatan yang dilakukan dengan pendekatan kuantitatif, dengan populasi sebanyak 138 orang. Kemudian diambil sampel sebanyak 103 orang dengan tingkat random sampling yang terdiri dari semua pengurus komite, Pengurus OSIS, ketua MGMP dan orangtua pengurus OSIS. Pengumpulan data dilakukan dengan teknik kuisioner, wawancara, dan dokumentasi. Data dianalisis dengan teknik analisis statistik deskriptif dengan menggunakan persentase, sedangkan pengujian hipotesis penelitian menggunakan uji F dan uji t yang diolah dengan program SPSS versi 20. Hasil penelitian menjelaskan Peran Komite Sekolah di SMA Negeri 2 Balige mempunyai rata-rata 167,21, yang jauh di atas rata-rata peran komite sekolah di SMA Negeri 1 Balige, yaitu 148.25. Sedangkan rata-rata Mutu Pendidikan di SMA Negeri 2 Balige adalah 172,48 yang juga lebih tinggi dari rata-rata mutu pendidikan di SMA Negeri 1 Balige yaitu 152,96. Perbedaan peran Komite sekolah akan meningkatnya mutu pendidikan berarti meningkatkan mutu sumber daya manusia, dengan meningkatnya sumber daya manusia memberikan peluang lebih besar kepada manusia untuk memiliki kesempatan lebih besar terhadap pilihan-pilihan hidup dan berkarya.
\end{abstract}

Kata kunci: komite sekolah, mutu pendidikan

\section{ANALYSIS OF SCHOOL COMMITTEE ROLE IN IMPROVING EDUCATION QUALITY IN KECAMATAN BALIGE KABUPATEN TOBA SAMOSIR (Comparative study of SMA Negeri 1 Balige and SMA Negeri 2 Balige)}

\begin{abstract}
This study aims to determine the differences in the role of school committees in SMA Negeri committees 2 Balige with the role of the school and SMA Negeri 1 Balige, and whether the different roles contribute to improving the quality of education in both schools. Approach are done with a qualitative approach, with a population of 138 people. Then taken a sample of 103 people with a random sampling consist of school committee the board of OSIS, the leader op MGMP, and the parents. The data were collected by questionare, interview and documentation. The data were analysed by descriptive statistic analysis technique using percentage. While testing the research hypothesis using F test and T test that is processed wiyh SPSS version 20 program. The result of the study explain the role of school committee SMA Negeri 2 Balige has on average of 167,21 which is far above the average role of school committee in SMA Negeri 1 Balige is 148,25. While the average quality of education in SMA Negeri 2 Balige is 172,48 which is also higher than the average quality of education in SMA Negeri 1 Balige is 152,96. The difference in the role of school committee which increase the quality of education means improving the quality of human resources, with increased human resources provide greater oppurtunities for human to have greater opportunities to the choice of life and work.
\end{abstract}

Key word: school committee, quality of education

\section{PENDAHULUAN}

Kesempatan masyarakat untuk bersamasama memperhatikan, mendukung serta membangun pendidikan memiliki wadah yang dinamakan komite sekolah. Masyarakat dapat menjalankan berbagai peran dalam penyelenggaraan dan pengendalian mutu pelayanan pendidikan baik melalui perorangan, kelompok, keluarga, organisasi profesi, pengusaha, maupun organisasi kemasyarakatan. Komite Sekolah terbentuk sesuai dengan Keputusan Menteri Pendidikan Nasional Republik Indonesia Nomor 044/U/2002 di dalam Salinan Lampiran II tanggal 2 April 2002 yang mengatakan bahwa Komite Sekolah adalah badan mandiri yang mewadahi peranserta masyarakat dalam rangka meningkatkan mutu, pemerataan, dan efisiensi pengelolaan pendidikan di satuan pendidikan, baik pada pendidikan pra sekolah, jalur pendidikan sekolah maupun jalur pendidikan luar sekolah.

Adapun tujuan dibentuknya Komite Sekolah sesuai SK Mendiknas Nomor 044/U/2002, 1) Mewadahi dan menyalurkan aspirasi dan prakarsa masyarakat dalam melahirkan kebijakan operasional dan program pendidikan di satuan pendidikan, 2) Meningkatkan tanggung jawab dan peranserta masyarakat dalam penyelenggaraan pendidikan di satuan pendidikan, 3) Menciptakan suasana dan kondisi transparan, akuntabel, dan demokratis dalam penyelenggaraan dan pelayanan pendidikan yang bermutu di satuan pendidikan. Partisipasi masyarakat selama ini pada umumnya lebih banyak bersifat dukungan dana tetapi dengan melihat kepada tujuan terbentuknya komite sekolah semakin jelaslah 
bahwa komite sekolah bukan hanya pemberi dukungan dana melainkan sebagai wadah yang mampu menampung aspirasi masyarakat, mampu melahirkan kebijakankebijakan yang sifatnya operasional sebagai wujud tanggung jawab masyarakat dalam penyelenggaraan pendidikan. Masyarakat, orang tua siswa yang diwakili komite sekolah bukan lagi penonton dari luar pendidikan melainkan talah ikut serta dalam melaksanakan perannya dalam pengambilan keputusan, monitoring, evaluasi dan akuntabilitas pelaksanaan pendidikan di sekolah.

Selanjutnya Keputusan Menteri Pendidikan Nasional Nomor. 044/U/2002 mengatur tentang Keanggotaan Komite Sekolah. Adapun keanggotaan Komite Sekolah terdiri dari 1). Unsur masyarakat dapat berasal dari: a. Orangtua/wali peserta didik, b. Tokoh masyarakat, c. Tokoh pendidikan, d. Dunia usaha/dunia industri, e. Organisasi profesi tenaga pendidikan, f. Wakil alumni, g. Wakil peserta didik. 2). Unsur dewan guru, yayasan/ lembaga penyelenggara pendidikan Badan Pertimbangan Desa maksimalnya 3 orang. Diharapkan jumlah anggota Komite Sekolah minimalnya sembilan orang dan jumlahnya gasal. Kepengurusan Komite Sekolah sekurang-kurangnya terdiri atas Ketua, Sekretaris, Bendahara dimana pengurus dipilih langsung dari dan oleh anggota serta Ketua Komite sekolah bukan berasal dari kepala satuan pendidikan.

Sebagai pemberi pertimbangan komite sekolah memberi masukan terhadap kebijakan dan program pendidikan. Seperti yang tertera pada Peraturan Menteri Pendidikan Nasional No. 19 Tahun 2007 tentang standar pengelolaan pendidikan, dalam lampirannya dikatakan bahwa penyusunan perencanaan program di sekolah seperti visi sekolah, misi sekolah, tujuan sekolah mendapat masukan dari komite sekolah. Demikian juga halnya dengan penyusunan rencana kerja sekolah yang memuat ketentuan mengenai kesiswaan, kurikulum dan kegiatan pembelajaran, pendidik dan tenaga kependidikan serta pengembangannya, sarana dan prasarana, budaya dan lingkungan sekolah, peran serta masyarakat dan kemitraan yang berkaitan dengan mutu lulusan yang ingin di capai untuk mendukung peningkatan mutu lulusan tersebut memperhatikan pertimbangan dari komite sekolah, apabila pelaksanaan kegiatan sekolah tidak sesuai dengan rencana yang sudah ditetapkan perlu mendapat persetujuan melalui rapat komite sekolah.

Menurut Kurniadin dan Machali (2012) pada satuan pendidikan, penguatan kapasitas tercermin dari kemampuan satuan pendidikan dalam melaksanakan proses pembelajaran efektif untuk mencapai standar nasional pendidikan. Untuk itu, perlu ditingkatkan kemampuan kepala sekolah, pendidik, dan tenaga kependidikan lainnya dalam memanfaatkan sumber daya pendidikan agar mendorong kegiatan belajar peserta didik secara optimal. Pada masa mendatang diharapkan informasi tentang kinerja satuan pendidikan dapat diakses oleh keluarga peserta didik dan masyarakat secara luas.
Sumber daya pendidikan dalam masyarakat dapat digunakanoleh komitesekolah dalampelaksanaanrencana sekolah, seluruh pelaksanaan rencana sekolah tidak dapat dilepaskan dari rencana anggaran pendapatan belanja sekolah, karena apapun yang hendak diprogramkan dan dikerjakan oleh sekolah secara keseluruhan pengurus komite sekolah dan orang tua diharapkan bersamasama memikirkan dan memutuskan demi kepentingan peserta didik. Menurut Fattah (2006) rencana anggaran pendapatan belanja sekolah dipengaruhi oleh misi dan faktor lingkungan pendidikan (sekolah). Lingkungan pendidikan dapat digolongkan menjadi lingkungan internal dan lingkungan eksternal. Tenaga kependidikan, sarana dan prasarana, kelengkapan fasilitas, dan biaya yang tersedia di setiap sekolah inilah yang disebut sebagai lingkungan internal sekolah.

Menurut Kurniadi dan Machali (2012) perencanaan adalah sebuah proses pengambilan keputusan yang dilakukan secara sistematis. Perencanaan berhubungan dengan masa mendatang dan untuk mencapai tujuan tertentu yang diinginkan. Perencanaan pendidikan mencakup 1). Tujuan, apa target yang hendak dicapai melalui perencanaan tersebut, 2). Posisi sistem pendidikan, bagaimana dengan kondisi sistem pendidikan saat ini, 3). Kebijakan dan prioritas yang bagaimana yang digunakan untuk mencapai tujuan, 4). Strategi yang bagaimana hendak dipergunakan dalam mencapai tujuan dari perencanaan tersebut.

Selanjutnya Kurniadin dan Machali (2012), menyebutkan ciri-ciri perencanaan pendidikan sebagai berikut, dalamperencanaan pendidikan(1)mengutamakan nilai-nilai manusiawi, 2). Memberi kesempatan untuk mengembangkan potensi peserta didik secara optimal, 3). Memberi kesempatan yang sama bagi peserta didik, 4). Komprehensif dan sistematis, 5). Berorientasi kepada pembangunan serta mempersiapkan sumber daya manusia yang dibutuhkan pada berbagai sektor pembangunan, 6). Pengembangannya dengan memperhatikan keterkaitannya dengan berbagai komponen pendidikan secara sistematis, 7). Menggunakan sumber daya secermat mungkin sebab sumber daya yang tersedia langka, 8). Berorientasi pada masa depan, 9). Responsif terhadap kebutuhan yang berkembang di masyarakat, 10). Sarana untuk mengembangkan inovasi pendidikan sehingga pembaruan terus-menerus berlangsung.

Peran komite sekolah sebagai pemberi pertimbangan, diharapkan mampu memberi masukan terhadap kriteria kinerja satuan pendidikan, untuk mampu membangun peningkatan proses belajar mengajar di sekolah. Peningkatan proses belajar mengajar di kelas secara langsung dikerjakan oleh tenaga pendidik. Menurut Mukhtar (2009) guru bertanggung jawab: 1). Menyiapkan sumber daya manusia yang berkualitas, beriman, bertakwa dan berilmu pengetahuan serta memahami teknologi. 2). Bagi kelangsungan hidup suatu bangsa, menyiapkan seorang pelajar untuk 
menjadi seorang pemimpin masa depan. Student today leader tomorrow. 3). Atas keberlangsungan budaya dan peradaban suatu generasi.

Peran Komite sekolah sebagai pendukung yaitu: 1). Mendorong orang tua dan masyarakat untuk berpartisipasi dalam pendidikan, 2). Menggalang dana masyarakat dalam rangka pembiayaan penyelenggaraan pendidikan, 3). Mendorong tumbuhnya perhatian dan komitmen masyarakat terhadap penyelenggaraan pendidikan yang bermutu. Hal itu semua dapat terwujud jika orang tua, masyarakat memiliki komitmen yang sungguh-sungguh dalam peningkatan mutu pendidikan. Seperti yang disampaikan Danim (2012) Setiap rupiah atau tenaga yang dikeluarkan oleh masyarakat dalam kerangka kegiatan pendidikan dan pembelajaran hendaknya bukan ditafsirkan sebagai harga sebuah sekolah, melainkan harga dari mutu proses dan produk pendidikan atau pembelajaran yang dikehendaki. Hubungan yang harmonis antara orang tua peserta didik, masyarakat dan pihak sekolah yang dijembatani oleh komite sekolah sangat diperlukan untuk menghasilkan pelayanan maksimal terhadap dunia pendidikan yang berdampak kepada peningkatan mutu pendidikan. Dalam rangka transparansi dan akuntabilitas penyelenggaraan dan keluaran pendidikan di satuan pendidikan, orang tua dan masyarakat diharapkan selalu mengikuti perkembangan proses pembelajaran dan pendidikan terhadap anak-anaknya serta melakukan evaluasi dan pengawasan. Menurut Undang-Undang Republik Indonesia Nomor 20 tahun 2003 tentang Sistim Pendidikan Nasional yang tertera pada pasal lima puluh empat ayat dua mengatakan masyarakat dapat berperan serta sebagai sumber, pelaksana, dan pengguna, penting masyarakat dilibatakan berperan serta dalam perencanaan, pelaksanaan, pengawasan, dan evaluasi program pendidikan.

Evaluasi yang dilakukan komite sekolah sekaitan dengan perannya sebagai pengontrol merupakan kegiatan identifikasi untuk melihat apakah suatu program yang telah direncanakan telah tercapai atau belum, berharga atau tidak, dan dapat pula untuk melihat tingkat efisiensi pelaksanaannya. Peran komite sekolah sebagai mediator diharapkan 1). Mampu melakukan kerjasama dengan masyarakat, 2). Menampung dan menganalisis aspirasi, ide, tuntutan, dan berbagai kebutuhan pendidikan yang diajukan oleh masyarakat. Dalam Mukhtar dan Iskandar (2009) mengatakan ada beberapa hal penting mengenai hubungan sekolah dan masyarakat: 1). Sekolah adalah bagian yang integral dari masyarakat; ia bukan merupakan lembaga yang terpisah dari masyarakat. 2). Hak hidup dan kelangsungan hidup sekolah bergantung pada masyarakat. 3). Sekolah adalah lembaga sosial yang berfungsi untuk melayani anggota-anggota masyarakat dalam bidang pendidikan. 4). Kemajuan sekolah dan kemajuan masyarakat saling berkorelasi; keduanya saling membutuhkan. 5). Masyarakat adalah pemilik sekolah; sekolah ada karena masyarakat memerlukannya. Menurut Pidarta (2009) kehadiran sekolah jangan menjadi menara air yang melebur menjadi satu dengan masyarakat tanpa memberikan identitas apa-apa, juga jangan menjadi menara gading yang menutup diri terhadap masyarakat sekitarnya melainkan jadilah menara penerang yang memberikan penerangan kepada masyarakat sekitarnya. Selanjutnya Mukhtar dan Iskandar (2009) menjelaskan tujuan hubungan sekolah dan masyarakat:a) Mengenalkan pentingnya sekolah bagi masyarakat, b) Mendapatkan dukungan dan bantuan morel maupun finansial yang diperlukan bagi pengembangan sekolah, c) Memberikan informasi kepada masyarakat tentang isi dan pelaksanaan program sekolah, d)Memperkaya atau memperluas program sekolah sesuai dengan perkembangan dan kebutuhan masyarakat, e) Mengembangkan kerja sama yang lebih erat antara keluarga dan sekolah dalam mendidik anak-anak.

Melalui peran dan dukungan komite sekolah diharapkan melahirkan sekolah yang bermutu. Pengembangan mutu dalam sektor pendidikan, sesungguhnya mengadopsi dari berbagai konsep. Menurut Sallis (2011) mutu dapat didefenisikan sebagai sesuatu yang memuaskan dan melampaui keinginan dan kebutuhan pelanggan. Sesuatu yang bermutu merupakan bagian dari standar yang sangat tinggi dan tidak dapat diungguli. Selanjutnya Danim (2012) mutu mengandung makna derajat keunggulan suatu produk atau hasil kerja, baik berupa barang maupun jasa. Barang dan jasa pendidikan itu bermakna dapat dilihat dan tidak dapat dilihat, tetapi dapat dirasakan.

Menurut Hamalik (1990) mutu dipandang dari dua sisi yaitu sisi normatif dan sisi deskriptif. Sisi normatif memandang mutu ditentukan oleh pertimbangan intrinsik dan ektrinsik. Kriteria intrinsik memandang mutu pendidikan merupakan produk pendidikan yakni manusia yang terdidik, sesuai dengan standar ideal. Berdasarkan kriteria ekstrinsik, pendidikan merupakan instrumen untuk mendidik tenaga kerja yang terlatih.

Hasil pendidikan dipandang bermutu jika mampu melahirkan keunggulan akademik dan ekstrakurikuler pada peserta didik yang dinyatakan lulus untuk satu jenjang pendidikan atau menyelesaikan program pembelajaran tertentu. Keunggulan akademik dinyatakan dengan nilai yang dicapai oleh peserta didik. Menurut Umiarso dan Gojali (2010) komponen yang terkait dengan mutu pendidikan yaitu: 1). Siswa, meliputi kesiapan dan motivasi belajarnya, 2). Guru, meliputi kemampuan profesional, moral kerja (kemampuan personal), dan kerja sama (kemampuan sosial, 3). Kurikulum, meliputi relevansi konten (isi) dan operasional proses pembelajarannya, 4). Sarana prasarana, meliputi kecukupan dan keefektifan dalam mendukung proses pembelajaran, 5). Masyarakat (orang tua, pengguna lulusan, dan perguruan tinggi) yaitu partisipasinya dalam 
pengembangan program-program pendidikan sekolah. Menurut Umiarso dan Gojali (2010) adapun indikator atau kriteria yang dijadikan tolok ukur mutu pendidikan yaitu hasil akhir pendidikan, hasil langsung pendidikan (hasil langsung inilah yang dipakai sebagai titik tolak pengukuran mutu pendidikan suatu lembaga pendidikan, misal: tes tertulis, daftar cek, anekdot, skala rating, dan skala sikap), proses pendidikan, instrumen input serta lingkungan.

Kebijakan peningkatan mutu pendidikan diarahkan pada pencapaian mutu pendidikan yang semakin meningkat yang mengacu pada Standar Nasional Pendidikan (SNP). SNP meliputi berbagai komponen yang terkait dengan mutu pendidikan mencakup standar isi, standar proses, standar kompetensi lulusan, standar pendidik dan tenaga kependidikan, standar sarana dan prasarana, standar pengelolaan, standar pembiayaan, standar penilaian.

Standar isi mengacu pada Peraturan Menteri Pendidikan Naisonal Nomor 20 tahun 2006, yang mencakup kerangka dasar kurikulum, struktur kurikulum, beban belajar, kurikulum tingkat satuan pendidikan, kalender pendidikan.

Peraturan menteri pendidikan nasional nomor 41 tahun 2007 tentang standar proses untuk satuan pendidikan dasar dan menengah, berisi: Rencana pelaksanaan pembelajaran; Pelaksanaan proses pembelajaran; Penilaian hasil pembelajaran; Pengawasan proses pembelajaran.

Standar kompetensi lulusan diatur dalam Peraturan Menteri Pendidikan Nasional Republik Indonesia Nomor 23 tahun 2006 yang berisi: (a) SKL untuk materi ujian tengah semester, ujian akhir semester, ujian sekolah hendaknya dibuat bersam-sama oleh tim guru mata pelajaran. (b) Dengan adanya SKL setiap sekolah di tingkat satuan pendidikan mengupayakan adanya peningkatan kualitas lulusan setiap tahunnya dan mewujudkan lulusan yang kompetitif di tingkat nasional. Sehingga berdampak pada mutu lulusan yang diterima di pendidikan/jenjang yang lebih tinggi.

Peraturan Menteri Pendidikan Nasional Republik Indonesia Nomor 16 tahun 2007 mengenai standar kualifikasi akademik dan kompetensi guru secara garis besar berisi: (1) Kualifikasi akademik guru, Kualifikasi tenaga pendidik sesuai dengan tuntutan BSNP (minimal S1). (2) Standar kompetensi guru. Menurut Keputusan Menteri Pendidikan Nasional Republik Indonesia No. 045/U/2002 Pasal satu, kompetensi adalah seperangkat tindakan cerdas, penuh tanggung jawab yang dimiliki seseorang sebagai syarat untuk dianggap mampu oleh masyarakat dalam melaksanakan tugas-tugas di bidang pekerjaan tertentu. Kompetensi guru meliputi kompetensi pedagogik, kompetensi kepribadian, kompetensi sosial dan kompetensi profesional yang diperoleh melalui pendidikan profesi.
Menurut Umiarso dan Gojali (2010) adapun komponen-komponen untuk mengukur keberhasilan guru mencakup: 1) Persiapan mengajar; 2) Pelaksanaan mengajar; 3) Hubungan Antarpribadi/Komunikasi.

Sesuai dengan Peraturan Menteri Pendidikan Nasional Republik Indonesia Nomor 24 tahun 2007 tentang standar sarana dan prasarana. Sekolah sangat membutuhkan sarana prasarana yang mendukung proses belajar mengajar untuk mencapai pendidikan yang berkualitas, antara lain: a.Sekolah mempunyai fasilitas yang bagus terhadap pengembangan pengetahuan IT; $b$. Sarana kelas, perpustakaan, laboratorium, sanitasi, dan IT yang sudah cukup memadai; c. Lokasi sekolah cukup strategis menjadi sekolah yang diminati masyarakat; d. Pemeliharaan fasilitas yang dilakukan secara berkesinambungan.

Peraturan Menteri Pendidikan Nasional Republik Indonesia Nomor 19 Tahun 2007 tentang standar pengelolaan pendidikan oleh satuan pendidikan dasar dan menengah berisi : a). Perencanaan program; b) Pelaksanaan rencana kerja; c) Pengawasan dan evaluasi; d) Kepemimpinan sekolah; e) Sistim informasi manajemen; f) Penilaian khusus.

Menurut Peraturan pemerintah Nomor 19 Tahun 2005 tentang standar Nasional pendidikan, Pasal 62 tentang Standar Pembiayaan pendidikan sebagai berikut: 1) Pembiayaan pendidikan; 2) Biaya investasi satuan pendidikan; 3) Biaya personal; 4) Biaya satuan operasi satuan pendidikan; 5) Standar biaya operasi satuan pendidikan.

Peraturan Menteri Pendidikan Nasional Republik Indonesia Nomor 20 Tahun 2007 tentang standar penilaian pendidikan. Standar penilaian pendidikan adalah standar nasional pendidikan yang berkaitan dengan mekanisme, prosedur, dan instrumen penilaian hasil belajar peserta didik.

Proses pembangunan suatu negara yang menjadi sasarannya adalah pengembangan sumber daya manusianya, karena semakin meningkat kualitas sumber daya manusianya maka pembangunan negara tersebut juga pasti meningkat dan meningkatkan kesejahteraan hidup. Pembangunan manusia yang meningkat memberi peluang lebih besar kepada manusia untuk membuat pilihan-pilihan berkarya dalam hidup ini. Manusia bukan hanya meningkat dari segi kemampuan tapi juga dapat mengupayakan pemanfaatan kemampuan tersebut untuk meningkatkan kesejahteraan hidup.

Seperti dikatakan Rachmat (2012) pada tahun 1990, United Nation Development Program (UNDP) memperkenalkan pengukuran pembangunan manusia yang dikenal dengan sebutan Human Development Index (HDI) atau Indeks Pembangunan Manusia (IPM). Menurut UNDP (1990), pembangunan manusia adalah suatu proses untuk mempebesar pilihan-pilihan bagi manusia. Dari definisi ini dapat ditarik kesimpulan bahwa fokus pembangunan suatu negara adalah 
penduduk karena penduduk adalah kekayaan nyata suatu negara. Sumber daya manusia yang bermutu tidak ada begitu saja, tetapi harus melalui suatu proses pendidikan, yang juga harus bermutu tinggi. Indeks Pembangunan Manusia (IPM) / Human Development Index (HDI) adalah pengukuran perbandingan dari indeks harapan hidup, indeks pendidikan (angka melek huruf dan lama bersekolah) dan indeks standar hidup layak untuk semua negara seluruh dunia. IPM digunakan untuk mengklasifikasikan sebuah negara kepada kategori negara maju, negara berkembang atau negara terbelakang.

Indeks Pembangunan Manusia (IPM) adalah pengukuran indeks harapan hidup, indeks pendidikan (angka melek huruf dan lama bersekolah) dan indeks standar hidup layak dirumuskan sebagai berikut:

$\mathrm{IPM}=1 / 3(\mathrm{X} 1+\mathrm{X} 2+\mathrm{X} 3)$

Di mana :

$$
\begin{aligned}
\mathrm{X} 1= & \text { Indeks Standar Hidup Layak } \\
\mathrm{X} 2= & \text { Indeks Pendidikan (Angka melek huruf dan } \\
& \text { rata-rata lama sekolah) } \\
\mathrm{X} 3= & \text { Indeks Harapan Hidup }
\end{aligned}
$$

Dari pengertian indeks pembangunan manusia salah satu indikatornya adalah pendidikan, demikian pentingnya pendidikan untuk meningkatkan mutu sumber daya manusia, dengan semakin berkualitasnya sumber daya manusia akan semakin meningkatkan IPM melalui formula yang telah ditetapkan diatas semakin tinggi IPM , idealnya IPM $=100$, semakin meningkat kesejahteraan hidup di wilayah tersebut.

\section{METODE}

Metode penelitian yang dijadikan sebagai dasar pelaksanaan pada penelitian ini merupakan penggabungan kualitatif dan kuantitatif. Dalam penelitian ini peneliti berusaha mencari permasalahan dan perbedaan fenomena, selanjutnya mencari arti atau manfaat dari adanya persamaan dan perbedaan yang ada.

Pada penelitian ini dua sekolah yang diteliti telah memiliki komite sekolah yang telah melaksanakan perannya, peneliti hendak melihat bagaimana pelaksanaan peran komite pada masing-masing sekolah tersebut, lalu melakukan komparasi.

Data primer diperoleh peneliti langsung dari komite sekolah dalam hal ini diwakili oleh pengurus komite, ketua musyawarah guru mata pelajaran, pengurus OSIS, orangtua pengurus OSIS dari kedua sekolah dalam bentuk observasi, wawancara, quetioner. Sedangkan data sekunder diperoleh peneliti dari masingmasing sekolah berupa data dalam bentuk dokumen dari Dinas Pendidikan Kabupaten Toba Samosir dan BPS Kabupaten Toba Samosir.

Populasi dalam penelitian ini berjumlah 138 orang. Perhitungan sampel pada penelitian ini dengan menggunakan rumus Slovin dan berjumlah 103 orang. Angket peran komite sekolah.

Peran komite sekolah dalam penelitian ini dilihat dari 4 fungsi komite sekolah dalam pendidikan, yaitu: peran komite sekolah sebagai pemberi pertimbangan, pendukung, pengontrol, dan sebagai mediator. Angket yang disusun memuat indikator-indikator fungsi tersebut. Angket peran komite sekolah dalam penelitian ini terdiri dari 40 item pertanyaan. Demikian juga dengan angket peningkatan mutu pendidikan juga sebanyak 40 item yang digunakan sebagai indikator adalah 8 standar pendidikan sesuai dengan PP No. 19 Tahun 2005 tentang Standar Nasional Pendidikan. Kelayakan instrumen dilakukan uji validitas dengan product moment. Uji reliabilitas digunakan rumus alpha, sedangkan teknik analisis data yang diterapkan pada penelitian ini yaitu reduksi data, penyajian data, penarikan kesimpulan (Verifikasi).

Menghitung normalitas dilakukan dengan menggunakan uji Liliefors (Sudjana, 2005). dan homogenitas dilakukan dengan uji Barlett, selanjutnya menguji Hipotesis dalam penelitian ini diuji dengan menggunakan uji beda $\mathrm{t}$ - test dengan sampel independen (Independent Sample T-Test).

\section{HASIL DAN PEMBAHASAN}

Skor angket tentang peran komite sekolah di SMA Negeri 2 Balige tersebar pada rentang $124 \mathrm{~s} / \mathrm{d}$ 193 dengan rata-rata skor 167.2115, standar deviasi 16.3327 dan varians 266.7583.

Skor angket tentang peranan komite sekolah di SMA Negeri 1 Balige tersebar pada rentang 119 s/d 180 dengan rata-rata skor 148.2500 , standar deviasi 15.4118 dan varians 237.5245.

Sedangkan Skor angket tentang peningkatan mutu pendidikan di SMA Negeri 2 Balige tersebar pada rentang $130 \mathrm{~s} / \mathrm{d} 200$ dengan rata-rata skor 172.4808, standar deviasi 16.1458 dan varians 260.6859. Data tentang peningkatan mutu pendidikan di SMA Negeri 1 Balige memiliki skor angket tentang peningkatan mutu pendidikan di SMA Negeri 1 Balige tersebar pada rentang $121 \mathrm{~s} / \mathrm{d} 183$ dengan rata-rata skor 152.9615, standar deviasi 15.8436 dan varians 251.0181.

Selanjutnya, untuk melihat apakah ada perbedaan yang signifikan (jelas dan nyata) antara peran komite sekolah di SMA Negeri 2 Balige dengan peran komite sekolah di SMA Negeri 1 Balige serta untuk melihat apakah ada perbedaan yang signifikan antara mutu pendidikan di SMA Negeri 2 Balige dengan mutu pendidikan di SMA Negeri 1 Balige, dapat dilihat pada Tabel 1.

Uji $t$ dua sampel dilakukan dalam dua tahapan; tahapan pertama adalah menguji apakah varians dari dua populasi bisa dianggap sama, setelah itu baru dilakukan pengujian untuk melihat ada tidaknya perbedaan rata-rata populasi. 
Tabel 1. Independent Samples Test

\begin{tabular}{|c|c|c|c|c|c|c|c|c|c|c|}
\hline & & \multirow{2}{*}{\multicolumn{2}{|c|}{$\begin{array}{c}\text { Levene's Test } \\
\text { for Equality of } \\
\text { Variances }\end{array}$}} & \multicolumn{7}{|c|}{ t-test for Equality of Means } \\
\hline & & & & & & & & & \multicolumn{2}{|c|}{$\begin{array}{l}95 \% \text { Confidence Interval of } \\
\text { the Difference }\end{array}$} \\
\hline & & $\mathrm{F}$ & Sig. & $\mathrm{T}$ & df & $\begin{array}{c}\text { Sig. } \\
\text { (2-tailed) }\end{array}$ & $\begin{array}{c}\text { Mean } \\
\text { Difference }\end{array}$ & $\begin{array}{l}\text { Std. Error } \\
\text { Difference }\end{array}$ & Lower & Upper \\
\hline \multirow[t]{2}{*}{ Komite_Sekolah } & $\begin{array}{l}\text { Equal } \\
\text { variances } \\
\text { assumed }\end{array}$ & .033 & .857 & 6.089 & 102 & .000 & 18.96154 & 3.11412 & 12.78470 & 25.13838 \\
\hline & $\begin{array}{l}\text { Equal } \\
\text { variances not } \\
\text { assumed }\end{array}$ & & & 6.089 & 101.658 & .000 & 18.96154 & 3.11412 & 12.78445 & 25.13863 \\
\hline \multirow[t]{2}{*}{ Mutu_Pendidikan } & $\begin{array}{l}\text { Equal } \\
\text { variances } \\
\text { assumed }\end{array}$ & .062 & .803 & 6.222 & 102 & .000 & 19.51923 & 3.13695 & 13.29710 & 25.74136 \\
\hline & $\begin{array}{l}\text { Equal } \\
\text { variances not } \\
\text { assumed }\end{array}$ & & & 6.222 & 101.964 & .000 & 19.51923 & 3.13695 & 13.29708 & 25.74138 \\
\hline
\end{tabular}

Dari hasil analisis data, terlihat bahwa $\mathrm{t}_{\text {hitung }}$ untuk peningkatan mutu pendidikan dengan Equal variance not assumed adalah 6,222 dengan probabilitas 0,000. Untuk uji dua sisi, probabilitas menjadi $0,000 / 2=0,000$. Oleh karena $0,000<0,025$, maka $\mathrm{H}_{0}$ ditolak. Penolakan $\mathrm{H}_{0}$ berarti bahwa rata-rata peningkatan mutu pendidikan di SMA Negeri 2 Balige berbeda secara signifikan dengan rata-rata peningkatan mutu pendidikan di SMA Negeri 1 Balige. Jika dilihat dari rata-rata kedua kelompok, peningkatan mutu pendidikan di SMA Negeri 2 Balige lebih tinggi dari rata-rata peningkatan mutu pendidikan di SMA Negeri 1 Balige (172.4808 > 152.9615).

Secara umum, pertanyaan penelitian yang ingin dijawab dalam penelitian ini ada 2. yaitu: (1) Adakah perbedaan pelaksanaan peran komite sekolah di SMA Negeri 2 Balige dengan peran komite sekolah di SMA Negeri 1 Balige, dan (2) Adakah perbedaan peningkatan mutu pendidikan di SMA Negeri 2 Balige dengan peningkatan mutu pendidikan di SMA Negeri 1.

\section{Tabel 2. Group Statistics}

\begin{tabular}{llcccc}
\hline & \multicolumn{1}{c}{$\begin{array}{c}\text { Sekolah } \\
\text { Konsumen }\end{array}$} & $\mathrm{N}$ & Mean & $\begin{array}{c}\text { Std. } \\
\text { Deviation }\end{array}$ & $\begin{array}{c}\text { Std. } \\
\text { Error } \\
\text { Mean }\end{array}$ \\
\hline $\begin{array}{l}\text { Komite } \\
\text { Sekolah }\end{array}$ & $\begin{array}{l}\text { SMA Negeri } \\
\text { 2 Balige } \\
\text { SMA Negeri }\end{array}$ & 52 & 167.2115 & 16.33274 & 2.26494 \\
& $\begin{array}{l}\text { 1 Balige } \\
\text { SMA Negeri } \\
\text { Putu }\end{array}$ & 52 & 148.2500 & 15.41183 & 2.13724 \\
Pendidikan & Balige \\
SMA Negeri & 52 & 172.4808 & 16.14577 & 2.23902 \\
& 1 Balige & 52.9615 & 15.84355 & 2.19711 \\
\hline \multicolumn{5}{c}{ Sumber : Hasil Olahan Data Peneliti, 2016 }
\end{tabular}

Hasil analisis data menunjukkan bahwa rata-rata peran komite sekolah di SMA Negeri 2 Balige berbeda secara signifikan dengan rata-rata peran komite sekolah di SMA Negeri 1 Balige. Dilihat dari table 4.2 rata-rata kedua kelompok, peran komite sekolah di SMA Negeri 2 Balige lebih tinggi dari rata-rata peran komite sekolah di SMA Negeri 1 Balige.Hal tersebut didasarkan atas empat indikator peran komite sekolah dalam dunia pendidikan yaitu peran sebagai pemberi pertimbangan, pendukung, pengontrol, dan sebagai mediator.

Dari hasil observasi dan wawancara, ada perbedaan rata-rata pelaksanaan peran komite sekolah, pada SMA Negeri 2 Balige secara keseluruhan pelaksanaan peran komite sekolah lebih baik karena pengurus komite sekolah sangat peduli memberhasilkan pelaksanaan pendidikan, pengajaran dan pelatihan terhadap peserta didik, proaktif terhadap perkembangan sekolah dan pelayanan yang diberikan sekolah kepada masyarakat, meskipun komite sekolah kecendrungannya hanya di wakili oleh ketua komite sekolah saja. Faktor lain komite sekolah yang dalam hal ini diwakili oleh ketua komite melakukan kunjungan yang dilaksanakan secara teratur ke sekolah tanpa harus diminta pihak sekolah sehingga penyelenggaraan sekolah terpantau dengan baik oleh komite sekolah, Mukhtar (2009).

Pada SMA Negeri 1 Balige secara keseluruhan komite sekolah kurang melaksanakan perannya dengan baik terlihat dari kurang pedulinya pengurus komite sekolah terhadap kebutuhan sekolah, mempercayakan pencarian dana yang dibutuhkan untuk pengembangan sekolah kepada manajemen sekolah. Selain itu pengurus komite sekolah sangat jarang melakukan kunjungan secara teratur ke sekolah untuk mengetahui perkembangan pelayanan terhadap masyarakat oleh sekolah.

Namun, secara umum manajemen sekolah SMA Negeri 2 Balige dan SMA Negeri 1 Balige memiliki keluhan yang sama terhadap minimnya bantuan orang tua melalui dana komite, sehingga diperlukan pengolahan keuangan sedemikian rupa yang berasal dari masyarakat melalui dana komite yang telah disepakati bersama orang tua melalui rapat komite sekolah.Hal ini tidak sejalan dengan yang dikatakan Damin (2012), bahwa segala rupiah atau tenaga yang dikeluarkan masyarakat 
merupakan harga untuk mendukung proses dan produk pendidikan.

Melalui Tabel 2. diperoleh, peningkatan mutu pendidikan di SMA Negeri 2 Balige lebih tinggi dari rata-rata peningkatan mutu pendidikan di SMA Negeri 1 Balige.

Peningkatan mutu pendidikan dilihat berdasarkan delapan standar nasional pendidikan (PP No.19 tahun 2005) yang mencakup standar isi, standar proses, standar kompetensi lulusan, standar pendidik dan tenaga kependidikan, standar sarana dan prasarana, standar pengelolaan, standar pembiayaan, dan standar penilaian pendidikan.

Standar isi yang ditetapkan di SMA Negeri 2 Balige dan di SMA Negeri 1 Balige sama-sama mengacu pada standar isi yang telah ditetapkan oleh pemerintah (permen No.20 tahun 2006). Revisi kurikulum pendidikan di SMA Negeri 2 selalu dilaksanakan di awal tahun pembelajaran. Hasil dari revisi kurikulum ini menghasilkan guru yang siap dalam melakukan aktivitas belajar mengajar, sesuai dengan Permen No.41 tahun 2007. Sementara itu di SMA Negeri 1 Balige, analisis kurikulum belum terlaksana sepenuhnya secara rutin setiap tahun.

Berkaitan dengan standar kompetensi lulusan (Permen No.23 tahun 2006), kedua sekolah ini menjadikan standar yang dibuat pemerintah digunakan sebagai pedoman penilaian dalam penentuan kelulusan peserta didik dari satuan pendidikan.

Standar pendidik dan tenaga kependidikan, SMA Negeri 2 Balige hanya memiliki satu orang guru yang belum berijasah sarjana, sedangkan di SMA Negeri 1 Balige masih ditemukan guru sebanyak lima belas orang yang belum berijasah sarjana, hal ini belum memenuhi ketentuan dalam Permen No 16 tahun 2007.

Berbicara tentang standar pengelolaan, kepala sekolah SMA Negeri 2 Balige menerapkan open managament dimana seluruh guru mempunyai kesempatan yang sama dalam pemberian masukan atas rencanarencana sekolah yang akan dilakukan. Sementara itu di SMA Negeri 1 Balige, fakta yang ditemukan di lapangan, manajemen yang dibangun kepala sekolah sangat diharapkan agar diberlakukan punishment and reward dari pimpinan.Jika dibandingkan dengan permen No. 19 tahun 2007, semua kegiatan yang dilakukan oleh kepala sekolah di kedua sekolah tersebut belumlah memenuhi, namun SMA Negeri 2 balige lebih baik dalam mengelola managemen sekolah.

Sarana dan prasarana di kedua sekolah ini terlihat sangat berbeda, SMA Negeri 2 Balige seluruh kelas telah menggunakan perangkat teknologi dalam pembelajaran, hal ini sudah memenuhi Permen No 24 tahun 2007 sedangkan di SMA Negeri 1 Balige proses pembelajaran berlangsung secara konvensional.

Standar pembiayaan dan standar penilaian kedua sekolah mengacu dengan standar yang ditetapkan oleh pemerintah melalui Dinas Pendidikan Kabupaten Samosir (Permen No 20 tahun 2007).

Dari hasil penelitian terlihat bahwa mutu pendidikan di SMA Negeri 2 Balige lebih baik dari mutu pendidikan di SMA Negeri 1 Balige, yang merupakan peran dari komite sekolah. Hal ini sejalan dengan hasil penelitian yang ditemukan (Armansyah 2009; Kurniawan, 2011; Fandy,2015), serta didukung dengan informasi nilai rata-rata UN dan persentase kelulusan di perguruan tinggi negeri dari masing-masing sekolah berikut ini.

Tabel 3. Persentase Kelulusan Ujian Nasional SMA Negeri 1 Balige dan SMA Negeri 2 Balige

\begin{tabular}{ccc}
\hline Sekolah & $\begin{array}{c}\text { SMA Negeri 2 } \\
\text { Balige }\end{array}$ & $\begin{array}{c}\text { SMA Negeri 1 } \\
\text { Balige }\end{array}$ \\
\hline Tahun Pelajaran 2013/2014 & $100 \%$ & $100 \%$ \\
Tahun Pelajaran 2014/2015 & $100 \%$ & $100 \%$ \\
Tahun Pelajaran 2015/2016 & $100 \%$ & $100 \%$ \\
\hline & & Sumber: Data sekunder
\end{tabular}

Tabel 4. Persentase Kelulusan di Perguruan tinggi Negeri SMA Negeri 1 Balige dan SMA Negeri 2 Balige

\begin{tabular}{ccc}
\hline Sekolah & $\begin{array}{c}\text { SMA Negeri } \\
\text { 2 Balige }\end{array}$ & $\begin{array}{c}\text { SMA Negeri } \\
\text { 1 Balige }\end{array}$ \\
Tahun Pelajaran 2013/2014 & $80,38 \%$ & $35 \%$ \\
Tahun Pelajaran 2014/2015 & $83 \%$ & $40 \%$ \\
Tahun Pelajaran 2015/2016 & $97 \%$ & $70 \%$ \\
\hline
\end{tabular}

Sumber: data Sekunder

Melalui peran komite sekolah dalam peningkatan mutu pendidikan di kecamatan Balige kabupaten Toba Samosir berdampak kepada lulusannya. Peningkatan mutu pendidikan di Kecamatan Balige mengakibatkan meningkatnya kualitas sumber daya manusia. Menurut Adisasmita (2005:12) “ Pengembangan wilyah adalah suatu proses yang disengaja untuk mencapai tujuan tertentu dalam pembangunan suatu wilyah", dengan terjadinya peningkatan mutu pendidikan di Kecamatan Balige menjadikan Kecamatan Balige menjadi pilihan utama tempat menimba ilmu bagi masyarakat yang berasal dari Kecamatan Balige itu sendiri dan yang berasal dari luar Kecamatan Balige. Hal ini tentu memberikan dampak bagi perekonomian masyarakat di Kecamatan Balige.

\section{SIMPULAN}

Terdapat perbedaan secara signifikan dalam pelaksanaan peran komite sekolah di SMA Negeri 1 dan SMA Neger 2 di Kecamatan Balige. Melalui perbedaan peran Komite Sekolah tersebut berdampak pada peningkatan mutu pendidikan di SMA Negeri 2 Balige lebih tinggi dari peningkatan mutu pendidikan di SMA Negeri 1 Balige. Dengan meningkatnya mutu pendidikan berarti meningkatkan mutu sumber daya manusia, dengan 
meningkatnya sumber daya manusia memberikan peluang lebih besar kepada manusia untuk memiliki kesempatan lebih besar terhadap pilihan-pilihan hidup dan berkarya, yang dapat meningkatkan kesejahteraan hidup sehingga berdampak positif dalam pengembangan suatu wilayah. Sejalan dengan itu diharapkan setiap sekolah mampu memberdayakan peran komite sekolahnya. Tugas dan fungsi komite sekolah antara lain mendorong tumbuhnya perhatian dan komitmen masyarakat terhadap penyelenggaraan pendidikan yang bermutu, mendorong orang tua dan masyarakat untuk berpartisispasi dalam pendidikan guna mendukung peningkatan mutu dan pemerataan pendidikan, dan menggalang masyarakat dalam rangka pembiayaan penyelenggaraan pendidikan di satuan pendidikan. (Panduan MBS; Direktorat Jendral Manajemen Pendidikan Dasar dan Menengah; 2006). Pembentukan Dewan Pendidikan dan Komite Sekolah merupakan tuntutan untuk lebih meningkatkan peran serta keluarga dan masyarakat. Tuntutan tersebut lahir seiring dengan terjadinya perubahan paradigma penyelenggaraan pemerintahan dari sentralisasi ke desentralisasi. Komite sekolah diharapkan menjadi mitra sekolah yang dapat mewadahi dan menyalurkan aspirasi serta prakarsa masyarakat dalam melahirkan kebijakan operasional dalam program pendidikan disekolah.

\section{DAFTAR PUSTAKA}

Adisasmita, Rahardjo. 2008. Pengembangan Wilayah Konsep dan Teori.Penerbit Graha Ilmu. Jakarta

Arikunto, Suharsimi, 2012. Dasar-Dasar Evaluasi Pendidikan". Jakarta, PT Bumi Aksara.

Armansyah 2009 dengan Penelitian dengan judul Peranan dan pemberdayaan komite sekolah dalam penyelenggaraan pendidikan SMANegeri di Kota Binjai

BPS, Tobasa Dalam Angka. BPS Kabupaten Toba Samosir

Danim, Sudarwan, 2012. Visi Baru Manajemen Sekolah. Jakarta, PT Bumi Aksara.

Fattah, Nanang, 2009. Ekonomi Dan Pembiayaan Pendidikan. Bandung, PT Remaja Rosdakarya.

Kunandar, 2011. Guru Profesional. Jakara, PT Rajagrafindo Persada.

Kurniadin, Didin \& Imam Machali, 2012. Manajemen Pendidikan Konsep Dan prinsip Pengelolaan Pendidikan. Jogjakarta, Penerbit AR-Ruzz Media.

Kurniawan, Bodi, 2011, Peran Komite Sekolah Dalam Meningkatkan Mutu Pendidikan di Madrasah Pembangunan UIN Jakarta.
Mukhtar \& Iskandar, 2009. Orientasi Baru Supervisi Pendidikan. Jakarta, Gaung Persada.

Pidarta Made, 2009. Landasan Kependidikan. Jakarta, PT Rineka Cipta.

Sallis, Edward, 2011. Manajemen Mutu Terpadu Pendidikan. Jogjakarta, Penerbit IRCiSoD.

Soetomo, 2010. Strategi-Strategi Pembangunan Masyarakat. Yogyakarta, Pustaka Pelajar.

Sukmadinata, Nana Syaodih, 2009. Landasan Psikologi Proses Pendidikan. Bandung, PT Remaja Rosdakarya.

Umiarso \&Imam Gojali, 2010. Manajemen Mutu Sekolah Di Era Otonomi Pendidikan. Jogjakarta, Penerbit IRCiSoD.

Yusuf, Fandy, 2015. Peran Komite Sekolah Dalam Upaya Peningkatan Mutu Pembelajaran Di SD Unggulan Aisyiyah Bantul.

Keputusan Menteri Pendidikan Nasional Republik Indonesia Nomor 044/U/2002 tentang Dewan Pendidikan Dan Komite Sekolah.

Undang-Undang Nomor 20 Tahun 2003 tentang Sistim Pendidikan nasional

Undang-Undang Nomor 14 Tahun 2005 tentang Guru dan Dosen

PP No. 19 Tahun 2005 tentang Standar Nasional Pendidikan

PP No. 17 Tahun 2010 tentang Pengelolaan dan Penyelenggaraan Pendidikan

Peraturan Menteri Pendidikan Nasional Nomor 22 Tahun 2006 tentang Standar Isi

Peraturan Menteri Pendidikan Nasional Nomor 16 Tahun 2007 tentang Standar Guru

Peraturan Menteri Pendidikan Nasional Nomor 19 Tahun 2007 tentang Standar Pengelolaan

Peraturan Menteri Pendidikan Nasional Nomor 20 Tahun 2007 tentang Standar Penilaian

Peraturan Menteri Pendidikan Nasional Nomor 23 Tahun 2007 tentang Standar Kompetensi Lulusan

Peratuarn Menteri Pendidikan Nasional Nomor 24 Tahun 2007 tentang Standar sarana Prasarana

Peraturan Menteri Pendidikan Nasional Nomor 41 tahun 2007 tentang standar Proses

RPJMD Kabupaten Toba Samosir 2011- 2017 